\title{
Gastric perforation caused by Strongyloides stercoralis: a case report
}

\author{
Strongyloides stercoralis kaynaklı mide perforasyonu: \\ Olgu sunumu
}

\author{
Gürkan ÖZTÜRK, ${ }^{1}$ Bülent AYDINLI, ${ }^{1}$ Fehmi ÇELEBİ, ${ }^{1}$ Nesrin GÜRSAN ${ }^{2}$
}

\begin{abstract}
Strongyloidiasis is a parasitosis caused by the female nematode of the Strongyloides stercoralis. S. stercoralis causes a chronic infection that is asymptomatic in $50 \%$ of chronically infected patients, and it can also affect the stomach. Gastric involvement causes symptoms mostly mimicking gastritis. We report herein a case of gastric perforation in a 37-year-old woman, which was thought to be caused by $S$. stercoralis.
\end{abstract}

Key Words: Strongyloides stercoralis; gastric involvement; perforation.
Stronglodiasis, Strongyloides stercoralis' in dişi nematodları tarafından oluşturulan bir parazitozdur. S. stercoralis olguların \%50'sinde asemptomatik olan ve mideyi etkileyebilen kronik bir enfeksiyon oluşturur. Mide tutulumu genelde gastriti taklit eden bulgulara neden olur. Biz burada 37 yaşındaki kadın hastada S. stercoralis'e bağlı oluştuğunu düşündüğ̈̈müz bir mide delinmesi olgusunu sunuyoruz.

Anahtar Sözcükler: Strongyloides stercoralis; mide tutulumu; delinme.
Strongyloidiasis is a parasitosis caused by the female nematode of the Strongyloides stercoralis. It is mainly a dermatologic and gastrointestinal disease. ${ }^{[1-5]}$ We report herein a case of gastric perforation caused by $S$. stercoralis.

\section{CASE REPORT}

A 37-year-old otherwise healthy woman from a rural area admitted to the emergency room with an acute abdominal pain. Her history revealed that she had experienced epigastric pain, heartburn, nausea, vomiting, and abdominal discomfort for the last five months and had received treatment for suspected gastritis. The abdominal pain had become more intense in the last 12 hours and gained in severity hourly. It was initially epigastric but hours later became diffuse and spread to the entire abdomen. She also had vomiting and nausea. On the physical examination, she had fever $\left(38.5^{\circ} \mathrm{C}\right)$, diffuse tenderness on the entire abdomen, rebound tenderness, and strong muscular defense. Leukocyte count was $15000 / \mathrm{mm}^{3}$ with lymphocyte predominance and eosinophilia. Plain abdominal radiographs revealed dilated intestinal loops with air-fluid le- vels and free air under the right hemi-diaphragm (Fig. 1). Ultrasound examination revealed mild to moderate free intraperitoneal fluid and dilated intestinal loops. The patient underwent emergent laparotomy with the preoperative diagnosis of gastrointestinal perforation. During the exploration, a $0.5 \mathrm{~cm}$ perforation was found on the posterior wall of the gastric corpus, at the base of a $2 \mathrm{~cm}$ in diameter gastric ulcer. The ulcer was excised with a $0.5 \mathrm{~cm}$ margin and sent for frozen section. The result of the frozen section was tumor negative. The defect at the posterior wall was then closed primarily.

The postoperative period was uneventful. Pathological examination of the excised ulcer revealed inflammatory changes and adult form of $S$. stercoralis at the site of perforation (Figs. 2, 3). The patient was consulted with the Department of Infectious Diseases and was evaluated for any immunodeficiency. The immunologic status of the patient was normal. Albendazole treatment at a dose of $10 \mathrm{mg} / \mathrm{kg}$ was recommended. The patient was discharged on the 10th day. She refused to take any further medication for the treatment of the disease or to present during the follow-up period. 


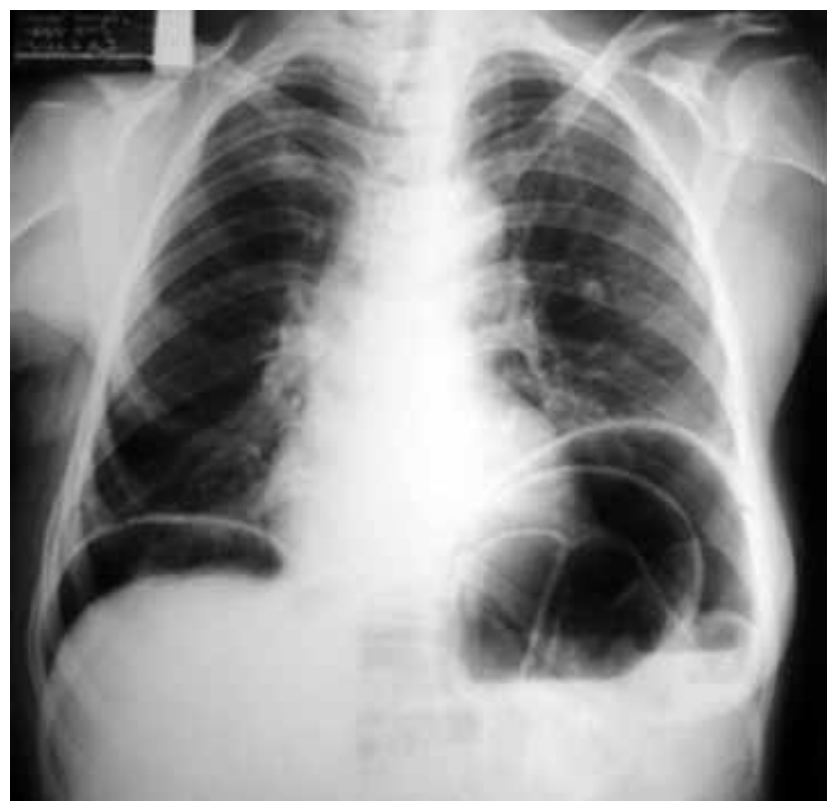

Fig. 1. Plain radiograph of the patient revealing bilateral subdiaphragmatic free air.

\section{DISCUSSION}

S. stercoralis is a helminth that infects the small intestine of humans, particularly the duodenum and the upper jejunum. ${ }^{[1,6,7]}$ It is widely distributed throughout tropical and subtropical regions of the world. Risk groups for acquiring the infection include residents and travelers to Southern, Eastern and Central Europe, Latin America, sub-Saharan Africa, and the Caribbean islands. ${ }^{[3,5-8]}$ Our patient was not from these regions and had not traveled outside the East Anatolian region of Turkey.

S. stercoralis causes a chronic infection, which is asymptomatic in $50 \%$ of chronically infected patients. ${ }^{[2,6]}$ This chronic state of the infection is caused by the autoinfection cycle of the parasite. This state can be accelerated with deficiency in the immune system. Iat-

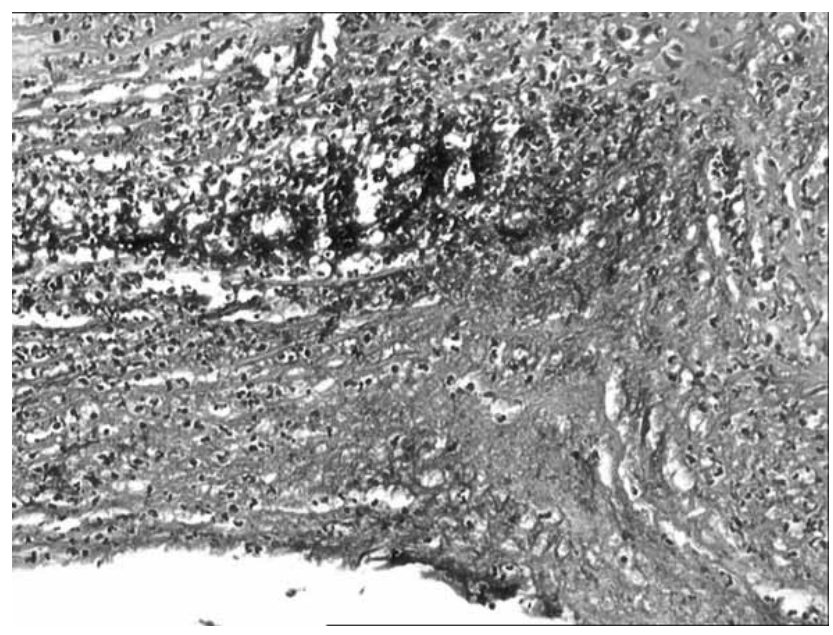

Fig. 2. Gastric biopsy revealed a moderate inflammatory infiltrate in the gastric mucosa. rogenic or disease-related immune deficiency causes hyperinfection and disseminated strongyloidiasis. ${ }^{[2-6,8]}$ It is reported that gastrointestinal involvement is commonly seen in patients with immunodeficiency, but Thompson et al. ${ }^{[7]}$ reported two cases that were immunocompetent. ${ }^{[1,7,9]}$ We investigated the immunological status of our patient, after the pathologic examination revealed $S$. stercoralis, and found that she was not immunocompromised. Further analyses for possible human immunodeficiency virus (HIV) infection were also negative.

It is reported that $S$. stercoralis can affect the stomach. ${ }^{[1,2,7,9-11]}$ Clinically, gastric involvement causes symptoms such as epigastric pain and tenderness, nausea and vomiting. ${ }^{[1,3,6,7]}$ All these also existed in the history of our patient. She received medical treatment for a suspected gastritis. The common feature of gastric mucosal injury is destruction of the mucosa, but gastric perforation was not reported previously, although the pathologic route of disseminated disease is invasion and ulceration of the wall. ${ }^{[6]}$

The diagnosis of this disease is commonly made on the basis of suspicion because the signs and symptoms are quite non-specific. Examination of a single stool sample will detect rhabdoid larvae $25 \%$ of the time. The sensitivity of the stool test can be elevated to $85 \%$ by using several tests. ${ }^{[3]}$ However, some other authors suggest that the diagnostic yield is not higher than $46 \%$, even after three stool examinations. ${ }^{[7]} \mathrm{We}$, however, performed only a single stool test and this was negative. Enzyme-linked immunosorbent assay could also be used for the diagnosis of strongyloidiasis with a sensitivity ranging from $68 \%$ to $95 \%{ }^{[3,7]}$ Endoscopic assessment and pathological examination, however, are very important. Reported endoscopic features for gastritis strongyloidiasis are small ulcerations and antral erythema and edema of the antrum, pylorus and duodenum. $^{[1,7]}$ S. stercoralis (filariform larvae) is fo-



Fig. 3. Numerous filariform larvae consistent with Strongyloides stercoralis. 
und on microscopic examination of gastric specimens and causes inflammatory infiltration of the mucosa, mimicking gastric mucosal inflammation, ulceration and hypertrophic pyloric stenosis..$^{[1,7,9]}$ These findings were also observed in our patient.

Treatment of $S$. stercoralis consists of orally administered ivermectin, thiabendazole and albendazo$1 \mathrm{e}^{[3,7,9]}$ treatments. We could not determine the effectiveness of the medical treatment because the patient refused to take any further oral treatment.

In summary, it is important to recognize that disseminated strongyloidiasis is most commonly seen in immunocompromised patients, but this case is an exception because it presented as a perforation in a patient who was not immunocompromised or living in an endemic area.

\section{REFERENCES}

1. Meine GC, Dietz J, Rocha M, Mattos T, de Souza AR, Conteletti FR. Atypical gastric presentation of strongyloidiasis in HIV-infected patient-case report. Dig Liver Dis 2004;36:7602.

2. Tzanetou K, Tsiodra P, Delis V, Frangia K, Karakatsani E, Efstratopoulos A, et al. Coinfection of Schistosoma mansoni and Strongyloides stercoralis in a patient with variceal bleeding. Infection 2005;33:292-4.

3. Concha R, Harrington W Jr, Rogers AI. Intestinal strongy- loidiasis: recognition, management, and determinants of outcome. J Clin Gastroenterol 2005;39:203-11.

4. Isotalo PA, Toye B, Eidus L. Human T-lymphotropic virus 1 adult T-cell lymphoma with Giardia and Strongyloides parasitism. Arch Pathol Lab Med 2000;124:1241.

5. Satoh M, Futami A, Takahira K, Kodaira M, Tanaka T, Kuriki K, et al. Severe strongyloidiasis complicated by meningitis and hydrocephalus in an HTLV-1 carrier with increased proviral load. J Infect Chemother 2003;9:355-7.

6. Daubenton JD, Buys HA, Hartley PS. Disseminated strongyloidiasis in a child with lymphoblastic lymphoma. J Pediatr Hematol Oncol 1998;20:260-3.

7. Thompson BF, Fry LC, Wells CD, Olmos M, Lee DH, Lazenby AJ, et al. The spectrum of GI strongyloidiasis: an endoscopic-pathologic study. Gastrointest Endosc 2004;59:90610.

8. Chieffi PP, Chiattone CS, Feltrim EN, Alves RC, Paschoalotti MA. Coinfection by Strongyloides stercoralis in blood donors infected with human T-cell leukemia/lymphoma virus type 1 in São Paulo City, Brazil. Mem Inst Oswaldo Cruz 2000;95:711-2.

9. Lambertucci JR, Leão FC, Barbosa AJ. Gastric strongyloidiasis and infection by the human T cell lymphotropic virus type 1 (HTLV-1). Rev Soc Bras Med Trop 2003;36:541-2.

10. Dees A, Batenburg PL, Umar HM, Menon RS, Verweij J. Strongyloides stercoralis associated with a bleeding gastric ulcer. Gut 1990;31:1414-5.

11. Wurtz R, Mirot M, Fronda G, Peters C, Kocka F. Short report: gastric infection by Strongyloides stercoralis. Am J Trop Med Hyg 1994;51:339-40. 